(C) The Author(s), 2021. Published by Cambridge University Press. This is an Open Access article, distributed under the terms of the Creative Commons Attribution licence (http://creativecommons.org/licenses/by/4.0/), which permits unrestricted re-use, distribution, and reproduction in any medium, provided the original work is properly cited. doi:10.1017/S1474746421000221

\title{
Are Older Adults' Leisure Patterns Consistent with the Active Ageing Model? The Influence of the Ageist Stereotypes
}

\section{José María Faílde Garrido* (D), María Dolores Dapía Conde** (D), Miguel Ángel Vázquez Vázquez*** and Lucía Vázquez Rodríguez ${ }^{\dagger}$}

*Facultad de Ciencias de la Educación University of Vigo and Galician Society of Gerontology and Geriatrics, Spain

E-mail: jfailde@uvigo.es

**Facultad de Ciencias de la Educación University of Vigo and Galician Society of Gerontology and Geriatrics, Spain

E-mail: ddapia@uvigo.es

***Facultad de Ciencias de la Educación University of Vigo and Galician Society of Gerontology and Geriatrics, Spain

E-mail: mvazquezv@uvigo.es

${ }^{\dagger}$ Galician Society of Gerontology and Geriatrics, Spain

E-mail: luciaglv@ucm.es

More and more studies indicate that leisure plays a fundamental role in active ageing. Our study describes the current leisure patterns of older adults, comparing them with other age groups. Consequently, 445 adults, stratified by age (young, middle-aged and older adults), were selected and subsequently administered a set of tests. The results indicate that older people claim having more time for their leisure activities; however, the diversity of activities performed is lower, showing a negative gradient based on age. The leisure patterns of older people reflect a predominance of passive leisure, little cultural leisure time and moderate levels of social and physical leisure activities. Older people's leisure seems to be influenced by ageist stereotypes and attribution biases. Our findings imply that these results could be used to design and implement programs aimed at promoting leisure styles that contribute to increase active ageing.

Keywords: Leisure, older adults, active ageing, ageism, attributions.

\section{Introduction}

The increase in the number of older people worldwide is a phenomenon widely recorded in international reports (United Nations, 2017). However, the demographic ageing of the population does not present a homogeneous distribution, with Europe being highlighted as the oldest continent; Spain, in this context, stands out as one of the oldest countries in the world (Eurostat, 2018), with Galicia - region located northwest of this country - as one of the Spanish communities with the highest ageing rates (Abellán et al., 2017).

In this ageing context, in scientific contexts as well as socio-political perspectives, there has been a growing concern in the last two decades about how to achieve 'good ageing'. 
This article has been theoretically framed within the 'active ageing' paradigm. This concept seeks a more holistic approach: rather than a healthy ageing, proposing (in addition to health as an area of care) social participation, security and lifelong learning. More and more studies indicate that the participation of older people in leisure activities plays a fundamental role for active ageing, increasing the chances of social integration and with important benefits in physical, mental health and quality of life (Eriksson Sörman et al., 2014; Fernández-Mayoralas et al., 2015; Alonso-Sánchez, 2017; Ryu and Heo, 2018). However, ageist attitudes can condition leisure patterns, negatively affecting active ageing (Cornwell et al., 2008; Cerquera et al., 2012; Lucas-Matheu, 2013; North and Fiske, 2013; Emile et al., 2014; Nunes et al., 2018).

In this research we have set out to describe the current leisure patterns of older adults, comparing them with other age groups and analysing whether these coincide with the attributions that others grant them. More specifically, we have considered the following secondary objectives to: 1) Determine the time and participation in different leisure activities in the different age groups; 2) Compare the attribution on the use of leisure time that a person perceives about themselves (self-attribution) with those attributed to an older person (hetero-attribution) in each of the age groups; 3) Identify reliable high participation predictors for the types of leisure studied (cultural, passive, social and physical).

We begin the article by briefly reviewing the active ageing construct and its relationship to leisure. Below we describe the methodology employed as well as the empirical results of the study. We conclude with a discussion section, including the implications of the results for future social policies in relation to the promotion of leisure for old people.

\section{Leisure patterns and active ageing}

In 2002 the WHO coined the term 'active ageing' and defined it as 'the process of optimising opportunities for health, participation and security in order to enhance quality of life as people age' (WHO, 2002: 79). Three strategic lines for the promotion of active ageing emerged from the definition itself: health, participation and security; a new strategic line, called 'lifelong learning', was added in 2015 (Kalache et al., 2015). Essentially, the insistence on the use of the word 'active' was due to a desire to express not only the ability to remain physically active, but also the idea that older adults should be involved in their own lives, as well as in social, political, economic, and educational matters. The emergence of this term and its widespread expansion in gerontological studies implies a change of perspective in the image of old age and ageing, switching from a negative vision centred on passivity or inactivity to a more positive image in which activity and the older adult as an autonomous and independent individual are prioritised (Marhánkova, 2011).

The confusion and lack of operativisation of the definition and components of 'active ageing' has led to multiple interpretations; it is sometimes limited to labour, an approach criticised by different authors (Foster and Walker, 2015; Walker and Zaidi, 2016). A broad, multidimensional model is currently being proposed, integrated by several different elements (Pinazo et al., 2010; Perales et al., 2014). Marsillas et al. (2017) argue that active ageing is a high-level construct composed of two broad categories of variables: status variables, which include elements related to health; and process variables, which represent different dimensions comprising both productive and leisure activities. 
Higher levels of active ageing are related to more time spent on leisure activities and greater social participation (Punyakaew et al., 2019). Participation, a pillar of active ageing, goes beyond work activity, integrating different areas and different activities of social, cultural, civic, or routine type of daily life (Fernández-Mayoralas et al., 2015). From this perspective, leisure expands the possibilities of integration and social participation, allowing to face the loneliness, frustration, or boredom of not knowing what to do, and interpersonal relationships, personal self-development, or optimism (Kim et al., 2017). Numerous studies endorse the benefits of older people's participation in leisure activities, both for specific aspects of physical or mental health and for more general purposes, such as satisfaction with life, personal well-being, or quality of life (Eriksson Sörman et al., 2014; Fernández-Mayoralas et al., 2015; Alonso-Sánchez, 2017; Ryu and Heo, 2018).

Our relationship with time is one of the aspects that changes in a great way as we age. Loss of professional activity or lower family burdens related to childcare, among other factors, explains why older people are more likely to have a lot of free time (Genoe et al., 2019), although sometimes this can bring on other challenges including caring for older relatives, or grandchildren, etc. Free time is understood as a measurable and quantifiable temporary space, available to individuals once their obligations (e.g. physiological, family) have been fulfilled. The amount of free time is different for each person and different factors influence it, including age and gender. Older people in general have more free time, but women have less - for these women, even in the retirement stage, free time often remains shorter. This is either because they do not experience work changes (they never had work outside the home) and/or because they continue with a greater role in domestic work and family care (Yerkes et al., 2020).

This increased availability of free time in the group of older adults is not always associated with a positive and pleasant experience of it, since it may generate uncertainties regarding how to use it. However, free time is a requirement for leisure; only the pleasant, self-servicing, and autonomous experience of that free time makes it leisure (Cuenca, 2009). However, the use of free time may be affected by stereotypes towards ageing, which include assumptions and generalisations that prescribe how older people should behave (LucasMatheu, 2013; Emile et al., 2014; Dionigi, 2015; Nunes et al., 2018).

To turn such free time into a positive experience (transforming it into enjoyment) is one of the greatest challenges for active ageing; within this framework, the principles of activity, independence, autonomy, and participation are the key aspects that should guide the organisation of leisure time in older adults. Their satisfaction and quality of life may vary depending on how they use their leisure time (Lee and Yeong, 2012; Cha, 2018).

\section{Method}

To determine the sample size, the program for epidemiological analysis from tabulated data (EPIDAT, version 4.1) was used, for a population size of 2.118.586 (inhabitants of Galicia ageing between eighteen and eighty-five years). With an expected proportion of 75 per cent a minimum absolute accuracy of 1 per cent and a maximum of 4 per cent, and a 95 per cent confidence level, the population size was 451 participants. However, considering the possibility of rejections and invalid questionnaires, an additional 5 per cent was recruited, leaving the sample at 478 . Finally, 455 participants were considered for the study, taking into account the negative ones (fifteen) and erroneous or incomplete questionnaires (eight). 
The selection of the participants began with a random, multi-stage cluster sampling. First, it was stratified by province, and selected for each stratum (habitat size); a sample proportional to the distribution of the population aged eighteen to eighty-five years; after that, the selection of the municipalities where the field study would be carried out was decided. Finally, in each municipality the census sections were selected to adjust the distribution to sampling points around seven participants (range five to nine). For the primary sampling units (provinces) the procedure was randomised, for the secondary ones (municipalities) and for the last units (individuals) it was mixed (random and intentional), setting quotas by age and gender, according to the distribution of the population. The response rate was 97 per cent.

The 'young' category (from eighteen to thirty-five) represented 33 per cent of the total with 145 participants; the 'middle-aged' category (from thirty-six to sixty-four years) represented 35 per cent with 154 participants; the 'older adults' category (sixty-five years or older) represented 33 per cent with 146 participants.

Regarding gender, 42 per cent were men and 58 per cent women, the latter being the majority in all age groups.

\section{Instruments}

Data collection was carried out by administering an integrated set of tests, evaluating leisure time uses, knowledge and stereotypes about old age and ageing, and satisfaction with own ageing. It also included several questions related to participants' socio-demographic data and other issues related to ageing. These instruments for assessment included the tools described below.

\section{Questionnaire on the Use of Time in Leisure Activities}

It was adapted from the original tool used by the Center for Research on Social Reality in its study on the use of time in Spain (CIRES, 1996), in which they gather information on the number of hours participants devote to different leisure activities on a weekly basis. Each participant had to answer how much time he/she devoted to different leisure activities and how long he/she thought older adults spent on these activities.

\section{The Facts on Ageing Quiz-1 (FAQ-1; Palmore, 1998)}

This questionnaire evaluates knowledge and attitudinal biases towards old age and ageing. It comprises twenty-five questions concerning physical, psychological, and social aspects related to ageing, as well as different stereotypes. Participants must choose the right answer among four alternatives through a multiple-choice format. The FAQ-1 is designed to measure knowledge; however, by means of a correction algorithm, it also determines positive and negative attitudinal biases, as well as the net attitudinal tendency. Total scores range from 0 to 25: the higher the score, the greater the knowledge about ageing and the health of older people. Internal consistency (Cronbach alpha) ranges from 0.45 to 0.66 (Pett et al., 2003; Williams et al., 2007). In this study, Cronbach's alpha was 0.62 . 


\section{Attitudes Towards Own Ageing Subscale (AHPE-PGCMS)}

It is comprised of items from the Philadelphia Geriatric Center Moral Scale (Lawton, 1975). This scale was used in previous studies (Liang and Bollen, 1983; Levy et al., 2002) as a tool to measure perceptions regarding 'good ageing'. It is composed of five items, the first four with dichotomous response format, while the fifth item offers three response options. Scores range from 0 to 5 : the higher the score the better the perception of ageing. Test-retest reliability ranged from 0.91 after five weeks to 0.75 after three months (Liang and Bollen, 1983). In the present study the Cronbach alpha was 0.73 , which indicates an adequate value of reliability of the scale used.

\section{Socio-demographic data and issues regarding ageing}

This section collected information on age, gender, marital status, employment status, political choice, religious beliefs and practice, cohabitation, and care of older people, as well as self-perceived knowledge about old age and ageing.

\section{Procedure}

The fieldwork was carried out by a research team with university training and having a socio-health profile, who were specifically trained to carry out this study.

All participants were provided with the same set of instruments, although the questionnaires were administered individually. In their administration, APA Ethical Guidelines for Research with Human Participants (Baltes et al., 1981) were taken into consideration, so all subjects were informed of the characteristics of the research, and their consent and collaboration were requested, asking for their sincerity, and informing that all the information collected would be treated confidentially. Refusal to participate was below 3 per cent.

\section{Design}

This is a transversal, descriptive study designed to be implemented by means of surveys. As dependent variables, we have used the attributes being assessed on the questionnaires described in the previous section, and as an independent variable we structured the participants by age, determining three age groups: young (18-35); middle age (36-64); and older adults (65-85).

\section{Data Analysis}

To analyse the data, univariate and multivariate statistical techniques were used. For the univariate descriptive analysis, we used central trend and dispersion statistics (means and typical deviations), frequency analysis, percentages, and analytical contrasts, using chisquare for categorical variables. After using the Kolmogorov-Smirnov test to verify the assumption of normality, which was not met, we decided to perform the contrasts for continuous variables using nonparametric tests: The Kruskal-Wallis H test (for $\mathrm{k}$ independent variable groups) and the Mann-Whiney $U$ test (for two independent groups) were 
used to perform post hoc contrasts where necessary; and the Wilkoxon signed-rank test (for two related groups) was implemented to detect significant differences $(p<0.05)$.

On the other hand, on the basis of classifying the different leisure activities, a theoretical categorisation was carried out that has been confirmed by an empirical procedure, using a factorial analysis (extraction method: analysis of main components).

Finally, binary logistic regression was used to identify the reliable predictors of each of the leisure categories (physical, cultural, social, and passive), which were used as dependent variables. As predictor variables they were used for each model: age, gender, marital status, employment status, political choice, religious beliefs and practice, cohabitation, and care of older people, as well as scores on the Ageing Knowledge scale (The Facts on Ageing Quiz-1) and on the scale of attitudes towards the ageing itself (Attitudes Towards Own Ageing Subscale).

\section{Results}

\section{Demographic and social attributes of the sample}

As shown in Table 1, no statistically significant associations between the variable stratification by age group and the variables gender and level of self-perceived knowledge about ageing were detected. On the other hand, a statistically significant association was found between the age stratification variable and the socio-demographic and classification variables described below, some predictable or expected due to participants belonging to each age group, such as level of education $\left(X^{2}=184.85, p=.000\right)$, marital status $\left(X^{2}=322.83, p=.000\right)$ or employment status $\left(X^{2}=408.10, p=.000\right)$. Older adults have a lower level of education, are married, or widowed to a greater extent, and their employment situation is defined by not studying or working and by being retired.

Statistically significant association was also found in relation to living with older adults $\left(X^{2}=11.72, p=.020\right)$; taking care of older adults $\left(X^{2}=19.72, p=.001\right)$; political choice $\left(X^{2}=33.45, p=.000\right)$, religious beliefs $\left(X^{2}=112.36, p=.000\right)$ and religious practices $\left(X^{2}=87.71, p=.000\right)$. Older people relay being ideologically right-wing more than other age groups, as well as having more religious beliefs and practicing their religion more often. In addition, the older age group reported having been involved in the care of an older adult the most, and together with the middle-aged group, they have also lived with people aged sixty-five or older most often.

\section{Time and participation in different leisure activities according to age group}

The total amount of time devoted to the fifteen leisure activities studied - the sum of weekly hours - is significantly higher in the older adults' group $\left(X^{2}=19.05, p=.000\right)$, which reflects the fact that they devote a significant part of their time to leisure: more specifically, 42 per cent of their hours per week, as opposed to 30 per cent for the middle-aged group. On average, older adults spend 9.98 hours per day in leisure activities (2.75 hours more than the middle-aged group and 0.84 hours more than the young). This total time is distributed unevenly in different activities regarding the different age groups studied.

Regarding self-attribution, of the fifteen activities analysed, those in which they declare investing more time are: 'watching television and/or listening to the radio' (18.92 hours) and 'resting, doing nothing' (16.33 hours). At a certain distance, with a weekly 
Table 1 Socio-demographic data and issues regarding ageing by age group

\begin{tabular}{|c|c|c|c|c|c|}
\hline & $\begin{array}{l}\text { Age } 18-35 \\
(\mathrm{n}=145)\end{array}$ & $\begin{array}{l}\text { Age 36-64 } \\
(\mathrm{n}=154)\end{array}$ & $\begin{array}{l}\text { Age }>65 \\
(n=146)\end{array}$ & $x^{2}$ & Sig. \\
\hline \multicolumn{6}{|l|}{ Sex } \\
\hline Male & $40.00 \%$ & $46.80 \%$ & $40.40 \%$ & \multirow[t]{2}{*}{1.77} & \multirow[t]{2}{*}{0,412} \\
\hline Female & $60.00 \%$ & $53.20 \%$ & $59.60 \%$ & & \\
\hline \multicolumn{6}{|l|}{ Level of Education } \\
\hline Elementary & $11.70 \%$ & $44.20 \%$ & $87.70 \%$ & \multirow[t]{3}{*}{184.85} & \multirow[t]{3}{*}{0.000} \\
\hline Secondary & $39.30 \%$ & $37.00 \%$ & $9.60 \%$ & & \\
\hline Higher & $49.00 \%$ & $18.80 \%$ & $2.70 \%$ & & \\
\hline \multicolumn{6}{|l|}{ Marital Status } \\
\hline Single & $87.60 \%$ & $13.60 \%$ & $9.60 \%$ & \multirow[t]{4}{*}{322.83} & \multirow[t]{4}{*}{0.000} \\
\hline Married & $11.00 \%$ & $72.70 \%$ & $53.40 \%$ & & \\
\hline Divorced & $0.70 \%$ & $11.70 \%$ & $3.40 \%$ & & \\
\hline Widowed & $0.70 \%$ & $1.90 \%$ & $33.60 \%$ & & \\
\hline $\begin{array}{l}\text { Has cohabitated with someone } \\
\text { over } 65\end{array}$ & $65.50 \%$ & $79.20 \%$ & $78.80 \%$ & 11.72 & 0.020 \\
\hline $\begin{array}{l}\text { Has taken care of someone } \\
\text { over } 65\end{array}$ & $40.00 \%$ & $50.60 \%$ & $63.70 \%$ & 19.72 & 0.001 \\
\hline \multicolumn{6}{|l|}{ Employment status } \\
\hline Studies. does not work & $34.50 \%$ & $1.90 \%$ & $0.00 \%$ & \multirow[t]{5}{*}{408.1} & \multirow[t]{5}{*}{0.000} \\
\hline Works. does not study & $29.00 \%$ & $66.20 \%$ & $7.50 \%$ & & \\
\hline Works and studies & $30.30 \%$ & $13.60 \%$ & $0.00 \%$ & & \\
\hline Neither Works nor studies & $6.20 \%$ & $18.20 \%$ & $43.20 \%$ & & \\
\hline Retired & $0.00 \%$ & $0.00 \%$ & $49.30 \%$ & & \\
\hline \multicolumn{6}{|l|}{ Political Choice } \\
\hline Right-wing & $9.10 \%$ & $18.20 \%$ & $34.50 \%$ & \multirow[t]{3}{*}{33.45} & \multirow[t]{3}{*}{0.000} \\
\hline Center & $34.70 \%$ & $38.60 \%$ & $38.90 \%$ & & \\
\hline Left-wing & $56.20 \%$ & $43.20 \%$ & $26.50 \%$ & & \\
\hline Has religious beliefs & $36.60 \%$ & $68.20 \%$ & $95.20 \%$ & 112.36 & 0.000 \\
\hline Practices their religion & $16.30 \%$ & $29.30 \%$ & $71.70 \%$ & 87.71 & 0.000 \\
\hline \multicolumn{6}{|l|}{$\begin{array}{l}\text { Self-perceived knowledge } \\
\text { regarding ageing }\end{array}$} \\
\hline Low & $17.20 \%$ & $15.60 \%$ & $13.70 \%$ & \multirow[t]{3}{*}{5.73} & \multirow[t]{3}{*}{0.220} \\
\hline Medium & $71.00 \%$ & $75.30 \%$ & $68.50 \%$ & & \\
\hline High & $11.70 \%$ & $9.10 \%$ & $17.80 \%$ & & \\
\hline
\end{tabular}

occupation of between five and eight hours, 'taking a walk' and 'taking a nap' (see Table 2) stand out, which would define a basically sedentary or low physical activity leisure pattern.

If we compare this data with the other two age groups, some similarities are perceived, although differences prevail. Thus, 'watching television and/or listening to the radio' and 'resting without doing anything' continue to be the activities to which all the groups refer to devoting the most time, although the average number of hours invested in them decreases. On the contrary, different activities occupy most of the time of young and middle-aged participants: 'going to bars and/or restaurants', 'going to listen to music', 
Table 2 Self-referred weekly hours devoted to different leisure activities by age group (test $\mathrm{H}$ de Kruskal-Wallis and post-hoc contrasts using the Mann-Whiney U statistic)

\begin{tabular}{|c|c|c|c|c|c|c|c|c|c|}
\hline & $\begin{array}{c}\text { Total } \\
\text { Average (Sx) }\end{array}$ & $\begin{array}{l}\text { Age 18-35 } \\
\text { Average(Sx) }\end{array}$ & $\begin{array}{l}\text { Age } 36-64 \\
\text { Average (Sx) }\end{array}$ & $\begin{array}{c}\text { Age }>65 \\
\text { Average }(S x)\end{array}$ & $X^{2}$ & Sig & $\begin{array}{c}\text { Post } \\
\text { Hoc } \\
U\end{array}$ & $p$ & Groups* \\
\hline Taking a nap & $3.35(4.01)$ & $2.18(2.71)$ & $2.07(2.87)$ & $5.87(4.87)$ & 76.71 & 0 & $\begin{array}{l}5426 \\
5536.5\end{array}$ & $\begin{array}{l}0 \\
0\end{array}$ & $\begin{array}{l}c>a \\
c>b\end{array}$ \\
\hline $\begin{array}{l}\text { Resting without doing } \\
\text { anything }\end{array}$ & $9.37(15.80)$ & $6.79(6.66)$ & $5.22(6.14)$ & $16.33(24.65)$ & 31.55 & 0 & $\begin{array}{l}8101.5 \\
7189.5\end{array}$ & $\begin{array}{l}0.001 \\
0\end{array}$ & $\begin{array}{l}c>a \\
c>b\end{array}$ \\
\hline Taking a walk & $5.51(5.71)$ & $3.65(3.06)$ & $4.40(5.05)$ & $8.52(7.08)$ & 60.4 & 0 & $\begin{array}{l}5480.5 \\
6351.5\end{array}$ & $\begin{array}{l}0 \\
0\end{array}$ & $\begin{array}{l}c>a \\
c>b\end{array}$ \\
\hline $\begin{array}{l}\text { Watching TV or listening to } \\
\text { the radio }\end{array}$ & $13.63(12.33)$ & $10.107 .57)$ & $11.96(9.94)$ & 18.92(16.15) & 31.45 & 0 & $\begin{array}{l}6730.5 \\
8144.5\end{array}$ & $\begin{array}{l}0 \\
0\end{array}$ & $\begin{array}{l}c>a \\
c>b\end{array}$ \\
\hline Going for drinks & $2.26(2.71)$ & $4.45(6.25)$ & $1.93(2.75)$ & $0.86(2.94)$ & 95.27 & 0 & $\begin{array}{l}4284 \\
7323\end{array}$ & $\begin{array}{l}0 \\
0\end{array}$ & $\begin{array}{l}a>c \\
b>c\end{array}$ \\
\hline $\begin{array}{l}\text { Going to restaurants and/or } \\
\text { bars }\end{array}$ & $5.25(8.73)$ & 6.28 (7.99) & $5.15(8.75)$ & $4.34(9.36)$ & 51.97 & 0 & $\begin{array}{l}5684 \\
8430\end{array}$ & $\begin{array}{l}0 \\
0\end{array}$ & $\begin{array}{l}a>c \\
b>c\end{array}$ \\
\hline $\begin{array}{l}\text { Going to the cinema or the } \\
\text { theater }\end{array}$ & $0.86(2.14)$ & $1.53(2.69)$ & $0.72(1.92)$ & $0.34(1.49)$ & 46.23 & 0 & $\begin{array}{l}6620.5 \\
9307\end{array}$ & $\begin{array}{l}0 \\
0.001\end{array}$ & $\begin{array}{l}a>c \\
b>c\end{array}$ \\
\hline Going to listen to music & $3.24(5.43)$ & $5.67(6.82)$ & $2.67(4.73)$ & $1.41(3.25)$ & 88.92 & 0 & $\begin{array}{l}4350.5 \\
8141\end{array}$ & $\begin{array}{l}0 \\
0\end{array}$ & $\begin{array}{l}a>c \\
b>c\end{array}$ \\
\hline Dancing & $1.35(2.72)$ & $2.28(3.12)$ & $0.73(1.95)$ & $1.10(2.78)$ & 46.11 & 0 & $\begin{array}{l}7322.5 \\
10759\end{array}$ & $\begin{array}{l}0 \\
0.404\end{array}$ & $\begin{array}{l}a>c \\
-\end{array}$ \\
\hline Reading & $3.31(5.06)$ & $4.11(5.04)$ & $3.11(4.68)$ & $2.74(5.41)$ & 18.62 & 0 & $\begin{array}{l}7632.5 \\
9862\end{array}$ & $\begin{array}{l}0 \\
0.064\end{array}$ & $\begin{array}{l}a>c \\
-\end{array}$ \\
\hline Sexual Intercourse & $2.55(2.87)$ & $3.38(2.86)$ & $3.44(3.24)$ & $0.85(1.40)$ & 117.9 & 0 & $\begin{array}{l}3707 \\
3876.5\end{array}$ & $\begin{array}{l}0 \\
0\end{array}$ & $\begin{array}{l}a>c \\
b>c\end{array}$ \\
\hline Speaking on the phone & $4.81(6.39)$ & $5.66(8.57)$ & $5.03(5.70)$ & $3.74(3.97)$ & 5.22 & 0.074 & $\begin{array}{l}9329 \\
9636\end{array}$ & $\begin{array}{l}0.078 \\
0.051\end{array}$ & $\begin{array}{l}- \\
-\end{array}$ \\
\hline
\end{tabular}




\begin{tabular}{|c|c|c|c|c|c|c|c|c|c|}
\hline Religious practices & $0.81(1.59)$ & $0.16(0.53)$ & $0.50(1.12)$ & $1.80(2.16)$ & 127.9 & 0 & $\begin{array}{l}3937.5 \\
5818.5\end{array}$ & $\begin{array}{l}0 \\
0\end{array}$ & $\begin{array}{l}c>a \\
c>b\end{array}$ \\
\hline Practicing sports & $3.07(4.46)$ & $5.03(5.43)$ & $2.26(3.40)$ & $1.96(3.68)$ & 65.48 & 0 & $\begin{array}{l}5362 \\
9830.5\end{array}$ & $\begin{array}{l}0 \\
0.05\end{array}$ & $\begin{array}{l}a>c \\
b>c\end{array}$ \\
\hline Shopping & $2.30(2.51)$ & $2.43(2.66)$ & $2.33(2.34)$ & $2.17(2.53)$ & 1.53 & 0.465 & $\begin{array}{r}9822 \\
10456\end{array}$ & $\begin{array}{l}0.279 \\
0.287\end{array}$ & - \\
\hline Total time of leisure (in hours) & $61.36(35.98)$ & $63.96(31.65)$ & $50.62(25.04)$ & $69.84(45.61)$ & 19.05 & 0 & $\begin{array}{r}10077 \\
7452.5\end{array}$ & $\begin{array}{l}0.833 \\
0\end{array}$ & $\begin{array}{l}- \\
c>b\end{array}$ \\
\hline
\end{tabular}

*a: Age 18-35; b: Age 36-64: c: Age>65 
'talking on the phone' or 'doing sports'; in comparison with older participants, the activities of 'taking a walk' or 'taking a nap' are not present in this ranking.

It is important to emphasise that statistically significant differences were found in relation to the time spent by the three age groups in thirteen of the fifteen leisure activities proposed (see Table 2); this implies differential and singular leisure patterns according to the participants' age. Only the time invested in 'talking on the phone' and 'shopping' did not reflect statistically significant differences.

On the other hand, Table 2 also shows that older people reported spending more time than other groups on five activities, resulting in the following statistically significant differences: 'Resting without doing anything' $\left(X^{2}=31.45, p=.000\right)$, 'resting without doing anything' $\left(X^{2}=31.55, p=.000\right)$, 'taking a walk' $\left(X^{2}=60.40, p=.000\right)$, 'taking a nap' $\left(X^{2}=76.71, p=.000\right)$ and 'religious practices' $\left(X^{2}=5127.90, p=.000\right)$. These analyses reflect the existence of statistically significant differences between the group of older adults and the group of young people in relation to the number of weekly hours they devote to the following activities: 'Taking a nap' $(U=5426.00, p=.000)$, 'resting without doing anything' $(U=8101.50, p=.001)$, 'taking walks' $(U=5480,50, p=.000)$, 'watching television and/or listening to the radio' $(U=6730.50, p=.000)$ and 'religious practices' $(U=3937.50$, $p=.000$ ). Similarly, statistically significant differences were found between the older adults and middle-aged groups regarding 'taking a nap' $(U=5536.50, p=.000)$, 'resting without doing anything' $(U=7189.50, p=.001)$, 'taking a walk' $(U=6351.50, p=.000)$, 'watching television and/or listening to the radio' $(U=8144, p=.000)$ and 'religious practices' $(U=5818.50, p=.000)$.

With regards to the remaining leisure activities, it is the group of young people who claim to devote the greatest number of weekly hours to them, with the only exception of the amount of time spent on having 'sexual intercourse', in which it is the middle-aged group that refers to investing the most time $\left(X^{2}=117.90, p=.000\right)$; subsequent analyses indicate that these differences occur between the middle-aged group and that of older adults $(U=3876.50, p=.000)$.

Therefore, there are certain activities to which older people seem to devote more time to (taking a nap, resting without doing anything, walking, watching television/radio and religious practices), and others that seem to be performed more often by young people (having drinks, going to the cinema or theatre, going to listen to music, dancing or doing sports).

Leaving aside the number of hours that participants devote to the different proposed activities, if we analyse the percentage of individuals per group who say they engage in some of them (see Figure 1), we observe that older people prefer to participate in the following leisure activities in greater proportion than other groups, in this order: 'taking a walk', 'resting without doing anything', 'taking a nap' and 'religious practices'.

Regarding the middle-aged group, the activities that they engage in the most are 'shopping' and 'talking on the phone'. In their part, young people are more likely to engage in 'practising sports', 'sexual intercourse', 'reading', 'going dancing', 'listening to music', 'going to the cinema/theatre', 'going to restaurants or bars', 'going for drinks' and 'watching television/listening to the radio'; although the latter is the activity most performed by all groups, with no statistically significant differences detected. 


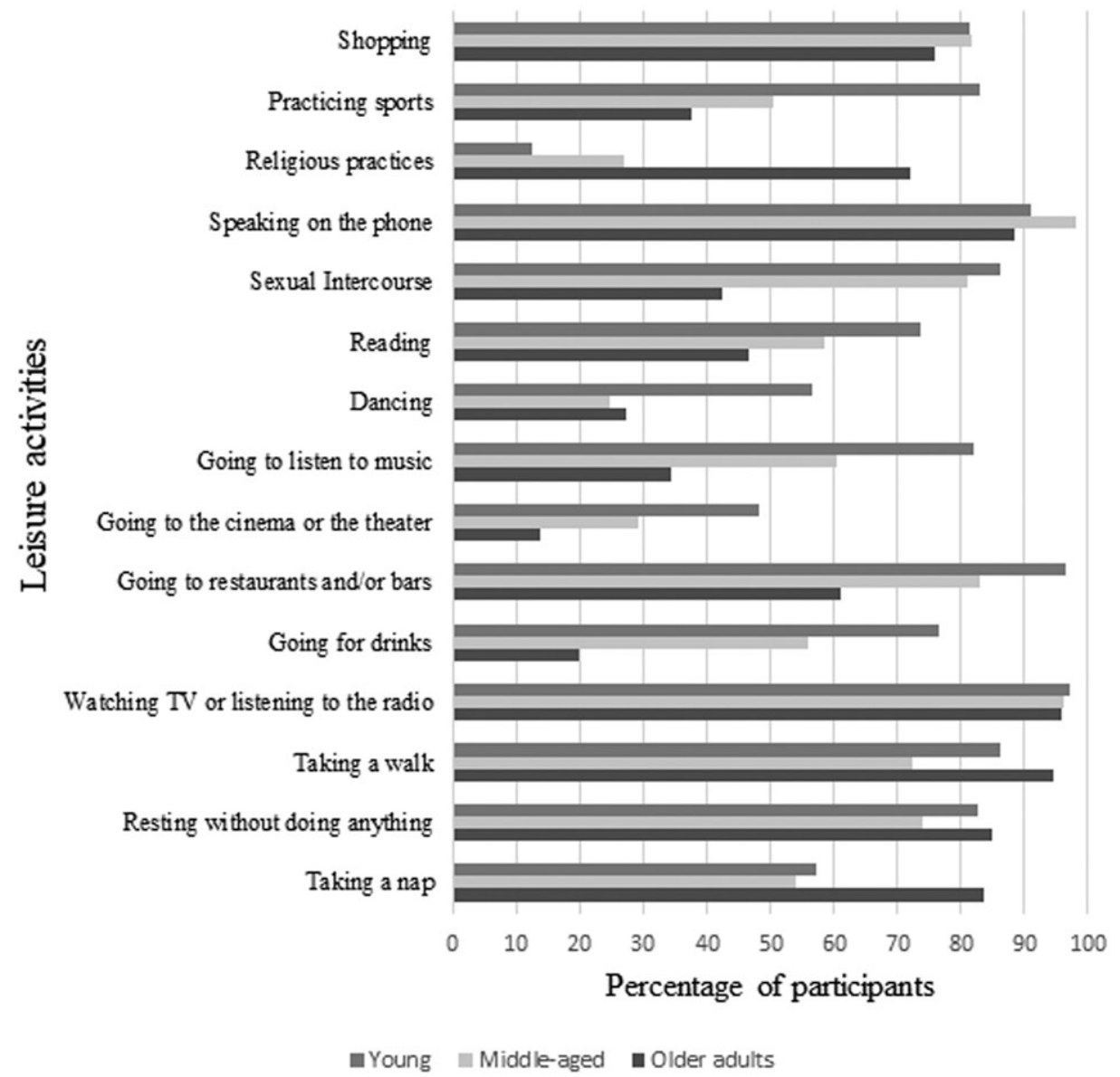

Figure 1. Percentage of participants per age group that claim to engage in different leisure activities

\section{Use of time in different leisure categories. Self-attributions and hetero-attributions}

From a literature review and a factorial analysis, the fifteen leisure activities were grouped into four modalities that explained 51.80 per cent of the variance. The categories have been called physical leisure, passive leisure, social leisure, and cultural leisure, which we briefly define: (i) Physical leisure: activities that require some kind of physical activity for its execution: for example, sport, walking, dancing; ii) Passive leisure: for example, activities of low involvement and personal demand, turning individuals into mere spectators or consumers (watching TV or listening to the radio, napping, resting, etc.); (iii) Social leisure: for example, those activities that involve some kind of social interaction (talking on the phone, religious practices, etc.); and iv) Cultural leisure: for example, activities with a priority purpose of creating and /or spreading different cultural manifestations (going to film, theatre, reading books, etc.).

Thus, after grouping the activities and contrasting them using the Kruscal-Wallis $H$ test, differences are again manifested between the three age groups (see Table 3) in 
Table 3 Self-attributions regarding the number of hours devoted to different leisure categories by age group (weighted averages and contrasts by Kruskal-Wallis $\mathrm{H}$ test and post-hoc with Mann-Whiney $\mathrm{U}$ statistic)

\begin{tabular}{|c|c|c|c|c|c|c|c|c|}
\hline & \multicolumn{5}{|c|}{ Self-attributions } & & & \\
\hline & Age 18-35 & Aoe 36-64 & $A \sigma e>65$ & & & \multicolumn{3}{|c|}{ Post Hoc } \\
\hline & Average $(S x)$ & Average $(S x)$ & Average (Sx) & $x^{2}$ & Sig & $U$ & $\mathrm{p}$ & Groups* \\
\hline Cultural leisure & $3.77(3.00)$ & $2.17(2.43)$ & $1.50(2.34)$ & 77.22 & 0 & $\begin{array}{l}4573 \\
8264.5\end{array}$ & $\begin{array}{l}0 \\
0\end{array}$ & $\begin{array}{l}\mathrm{c}<\mathrm{a} \\
\mathrm{c}<\mathrm{b}\end{array}$ \\
\hline Social leisure & $3.71(3.17)$ & $2.99(2.57)$ & $2.58(2.39)$ & 29.51 & 0 & $\begin{array}{l}6810 \\
9201.5\end{array}$ & $\begin{array}{l}0 \\
0.007\end{array}$ & $\begin{array}{l}\mathrm{c}<\mathrm{a} \\
\mathrm{c}<\mathrm{b}\end{array}$ \\
\hline Passive leisure & $6.36(4.03)$ & $6.42(4.60)$ & $13.70(12.01)$ & 64.94 & 0 & $\begin{array}{l}5559.5 \\
6020\end{array}$ & $\begin{array}{l}0 \\
0\end{array}$ & $\begin{array}{l}c>a \\
c>b\end{array}$ \\
\hline Physical leisure & 3.57 (2.06) & $2.71(2.15)$ & $3.02(2.21)$ & 17.99 & 0 & 7232 & 0 & $a>b$ \\
\hline
\end{tabular}

*a: Age 18-35; b: Age 36-64: c: Age>65 
cultural leisure $\left(X^{2}=72.22, p=.000\right)$, social $\left(X^{2}=29.51, p=.000\right)$, passive $\left(X^{2}=64.94\right.$, $p=.000)$ and physical leisure $\left(X^{2}=17.99, p=.000\right)$. Two-way post-hoc contrasts using the Mann-Whiney $U$ statistic showed that older adults spend more hours on passive leisure than younger people $(U=5559.50, p=.000)$ and middle-aged adults $(U=6010.00$, $p=.000)$. On the other hand, older people devote fewer hours to cultural $(U=4573.00$,

$p=.000)$ and social $(U=6810.00, p=.000)$ leisure activities than younger people; similarly, older people invest less time in cultural $(U=8264.50, p=.000)$ and social $(U=9201.50$, $p=.007$ ) leisure activities than middle-aged participants. Finally, in relation to physical leisure, no differences are identified between older adults and the other age groups, but there were significant differences found between young and middle-aged participants $(U=7232.00, p=.000)$.

To have a thorough and accurate study of the time devoted to different leisure categories, an analysis was carried out based on gender and level of studies, through the non-parametric Kruskal-Wallis test. In relation to the gender variable, the analyses revealed the absence of statistically significant differences in all kinds of leisure. These differences were also not found when we segmented the sample according to the three age groups studied. On the contrary, statistically significant differences were detected depending on the variable level of studies for the different leisure modalities: physical $\left(X^{2}=16.07, p=.000\right)$, cultural ( $\left.X^{2}=80.95, p=.000\right)$, social $\left(X^{2}=10.16, p=.006\right)$ and passive $\left(X^{2}=8.04, p=.018\right)$. When the sample was segmented by age group, there were statistically significant differences for middle-aged groups - in the categories of cultural leisure $\left(X^{2}=19.32, p=.000\right)$ and social $\left(X^{2}=8.87, p=.012\right)$ - and for the group of older adults - in three leisure categories: physical $\left(X^{2}=6.60, p=.037\right)$, cultural $\left(X^{2}=7.18, p=.028\right)$, and passive $\left(X^{2}=10.43, p=.005\right)$ However, these differences were not found in the youth group.

In order to identify the self-attributions of each group, we have compared these with the hetero attributions assigned to older adults in relation to the time spent on different types of leisure. Thus, the differences in the average weekly hours attributed to oneself (self-attributions) and to an older adult (hetero attributions) in the four categories studied were all statistically significant for the young group; there were statistically significant differences in three of the categories for the middle-aged group; and in two of the categories for older adults (see Table 4). A gradient based on age was observed, so that as age progresses, the differences between self-attributions and hetero attributions are reduced.

Besides this, in the modalities of cultural, social, and physical leisure the groups of young people attain higher scores in self-attributions; however, these are lower than hetero attributions regarding passive leisure. A similar pattern is observed for the middleaged group. On the contrary, in the group of older adults the pattern regarding cultural, social, and physical leisure activities is reversed, meaning that hetero-attributions achieve higher scores than self-attributions; the differences between the weighted averages of selfattributions and hetero-attributions with respect to passive leisure are also less marked, where all the groups attribute fewer hours to themselves than to an older adult.

\section{Predictors associated with different leisure categories}

Finally, in order to deepen our understanding of the relationship between the high participation (scores above the 75th percentile) in the different types of leisure activities analysed and socio-demographic data, knowledge and level of satisfaction with ageing, 
Table 4 Attributions regarding the use of time (in weekly hours) that a person perceives about oneself (self-attributions) and about an older person (heteroattributions) depending on the age group (contrast by Wilkoxon test)

\begin{tabular}{|c|c|c|c|c|c|c|c|c|c|c|}
\hline \multirow[b]{2}{*}{ Leisure } & & \multicolumn{3}{|c|}{$\begin{array}{c}\text { Young } \\
\text { (aged 18-35) }\end{array}$} & \multicolumn{3}{|c|}{$\begin{array}{l}\text { Middle-aged } \\
\text { (aged 36-64) }\end{array}$} & \multicolumn{3}{|c|}{$\begin{array}{c}\text { Older adults } \\
\text { (aged } 65 \text { or older) }\end{array}$} \\
\hline & & Average(Sx) & z & $p$ & Average(Sx) & z & $p$ & Average $(S x)$ & z & $p$ \\
\hline \multirow[t]{2}{*}{$\overline{\text { Cultural }}$} & Self & $3.77(2.8)$ & 7.57 & 0 & $2.18(2.4)$ & -5.37 & 0 & $1.52(2.3)$ & -1.5 & 0.135 \\
\hline & Hetero & $1.61(1.7)$ & & & $1.07(1.5)$ & & & $1.75(2.2)$ & & \\
\hline \multirow[t]{2}{*}{ Social } & Self & $3.73(3.2)$ & 3.57 & 0 & $3.01(2.5)$ & -1.96 & 0.05 & $2.52(2.3)$ & -2.07 & 0.038 \\
\hline & Hetero & $2.84(2.2)$ & & & $2.55(2.0)$ & & & $2.86(2.19)$ & & \\
\hline \multirow[t]{2}{*}{ Passive } & Self & $6.43(4.0)$ & 7.95 & 0 & $6.29(4.5)$ & 10.07 & 0 & $13.71(12.1)$ & -5.07 & 0 \\
\hline & Hetero & $13.4(11.3)$ & & & $15.76(10.3)$ & & & $17.50(13.8)$ & & \\
\hline \multirow[t]{2}{*}{ Physical } & Self & $3.61(2.0)$ & 4.48 & 0 & $2.66(2)$ & -0.66 & 0.508 & $2.98(2.2)$ & -0.45 & 0.651 \\
\hline & Hetero & $2.66(1.9)$ & & & $2.84(2.3)$ & & & $3.13(2.6)$ & & \\
\hline
\end{tabular}


Table 5 Final logistic regression model with reliable predictors and quantifying coefficients of high participation in different types of leisure in older adults

\begin{tabular}{|c|c|c|c|c|c|c|c|}
\hline Sample/Predictors & B & S.E. & Wald & Sig. & $\mathrm{gl}$ & OR & I.C. $95 \%$ \\
\hline \multicolumn{8}{|l|}{$\overline{\text { Cultural Leisure }}$} \\
\hline Level of Education & 0.86 & 0.42 & 4.23 & 0.04 & 1 & 2.36 & $(1.042-5.334)$ \\
\hline Sex & -0.87 & 0.42 & 4.28 & 0.039 & 1 & 0.41 & $(.181-.955)$ \\
\hline \multicolumn{8}{|l|}{ Passive Leisure } \\
\hline Satisfaction with Own Ageing & -0.42 & 0.15 & 8.01 & 0.005 & 1 & 0.65 & $(.487-.877)$ \\
\hline Knowledge Regarding Ageing & -0.16 & 0.08 & 4.06 & 0.044 & 1 & 0.85 & $(.730-.996)$ \\
\hline \multicolumn{8}{|l|}{ Social Leisure } \\
\hline Political views & 0.62 & 0.3 & 4.34 & 0.037 & 1 & 1.85 & $(1.037-3.309)$ \\
\hline \multicolumn{8}{|l|}{ Physical Leisure } \\
\hline Age & -0.08 & 0.03 & 5.41 & 0.02 & 1 & 0.93 & $(.870-.988)$ \\
\hline
\end{tabular}

four binary logistic regression equations were adjusted (Enter method). The group of participants aged sixty-five and over was selected as a study group to quantify the importance of the existing relationship between each of the covariates referred to above with the different leisure modalities (see Table 5). The Hosmer and Lemeshow test indicated a good level of adjustment of the four models, not detecting significant differences between the estimated and observed values for: Cultural Leisure $(p=.247)$, explaining 7.3 per cent of the variance (statistical Nagelkerke); Passive Leisure $(p=.145)$, explaining 16 per cent; Social Leisure $(p=.619)$, the variance explained by the model was 9.9 per cent; and Physical Leisure $(\mathrm{p}=.681)$, explaining 11 per cent of the variance.

Regarding reliable predictors for each of the four leisure modalities, they were: having a high level of education $(p<.05)$ and being male $(p<.05)$ for Cultural Leisure; a low level of knowledge regarding ageing $(p<.05)$ and low satisfaction with ageing $(p<.05)$ for Passive Leisure; left-wing political ideology $(p<.05)$ for Social Leisure; and age $(p<.05)$ for Physical Leisure, indicating that at a higher age fewer hours are devoted to activities related to physical leisure.

\section{Discussion}

This study has attempted to address leisure in older adults by comparing their activities with those of other age groups. There is not a large amount of research that opts for this comparative approach, since it is more common to find studies that focus on some of the groups: for example, only in young people (Felez-Nobrega et al., 2020), or only in older adults (Yamashita et al., 2019), etc. Nevertheless, it must be acknowledged that the study of leisure activities must be seen from an evolutionary perspective covering the entire life cycle, reflecting the particular reality of each age group as well (Monteagudo and Cuenca, 2012). Although leisure is a relevant factor for people's well-being throughout the life cycle, it plays a more relevant role in the final stage (Bardo, 2017). The analysis of the total amount of time self-attributed to the leisure activities studied reflects that it is older adults who invest the most time in them, delivering statistically significant data consistent with what was reported in Sancho's study (2006). Along similar lines, the report by Rodríguez 
et al. (2012) confirms this trend, with people over the age of sixty-five being the most involved in leisure activities. The increase in the time devoted to leisure activities after retirement is related to the greater free time available because of the decrease in work and family obligations (Kleiber and Linde, 2014; Genoe et al., 2019) and it correlates positively with life satisfaction (Cha, 2018). Therefore, it is not surprising that free time in this stage is of vital importance being, for almost half of the older population, the main activity in a working day (Díaz, 2012).

However, the most important aspect analysed in this study is related to the ways in which said leisure time is filled. Therefore, if we analyse the activities mostly practised by the participants, we observe that four stand out from the others, with a percentage of realisation ranging from 80 to 95 per cent. Such activities are, in descending order: 'watch TV and/or listen to the radio', 'talk on the phone', 'walk' and 'rest without doing anything'. In addition, two of these, the first and the last, are the ones to which the groups spend the most hours, being the group of people who add the most time. This reflects a greater investment of hours in passive leisure than in active. We understand by active leisure that type of leisure that requires some effort or involvement not only physical but also intellectual or social interaction; on the contrary, a passive leisure practice would require little physical or other involvement. Applied to the taxonomy used in this research, active leisure would include the categories of physical, social, and cultural leisure while passive leisure would be the equivalent of the one given the same name. Active leisure, in addition to its obvious health benefits, as Madrigal (2000: 4) says, 'is an effective remedy to alleviate loneliness', in the face of passive leisure that 'acts in the opposite direction'.

It should be noted that, just as we observe that the group of older adults is the one that spends the least time practicing sports, it is, however, the one that invests, as we mentioned, the most time in walking; a physical activity that is indicated to their age and also increases the possibilities of contact and social interaction, relevant factors for the active ageing of older adults (WHO, 2010; Chang et al., 2014).

Two seemingly contradictory conclusions are derived from the results of the comparative analysis of the leisure patterns in older adults as opposed to those shown by the other age groups: 1 ) their leisure practices are quite like those of the population as a whole and 2) differences are manifested according to age.

From a qualitative perspective, older adults' leisure is characterised by predominantly passive leisure activities, little cultural leisure time and a slightly higher participation in social and physical leisure activities. This pattern is remarkably similar to the other two age groups studied. Yet, older adults spend significantly more hours per week on passive leisure and less social and cultural leisure than young people and adults; and without differences in the number of hours dedicated to physical leisure. These conclusions are partially concordant with those collected in different studies. Acosta et al. (2014) conclude that leisure activities that are essentially social and that are regularly carried out outside the home are the first to significantly reduce their frequency as we age. The work of Lardiés-Bosque et al. (2013) confirms the tendency to watch television as an activity practiced with greater frequency by older adults, as opposed to going to the cinema or the theatre (less than half) and physical activity, which are practiced less frequently.

Summarising, older people refer having more time for their leisure activities, although the diversity of activities they engage in decreases with age. This means that young people seem to present leisure patterns integrating a greater variety of activities than middle-aged people and these, in turn, participate in more varied leisure activities than older adults. 
Different studies (Sancho, 2006; Díaz, 2012; Cuenca et al., 2013; Lardiés-Bosque et al., 2013; Cha, 2018; Punyakaew et al., 2019) confirm the trend reflected in this research, defined by a highly widespread practice among older people consisting of watching television and/or listening to the radio, which together with other activities (e.g. resting, napping) also practised with high frequency indicates a pattern showing a high predominance of passive and static forms of leisure in older adults.

The dichotomy between active and passive leisure and the empirical verification of a predominance of passive forms of leisure in older adults, in which they assume the role of spectators rather than becoming actors, raises the question whether leisure really constitutes a valuable, satisfactory experience of personal development for older adults. In other words, these findings further illuminate the debate concerning whether only active leisure activities are important and profitable for active ageing or, on the contrary, participation in any type of leisure activity, regardless of the degree of personal involvement, promotes active ageing. Some authors argue that a sole focus on active practices is not what affects perceived subjective well-being (Cuenca et al., 2013), but rather, it is the quality of practices and the personal attitude that really makes a difference. For leisure activities to become a satisfactory experience, reaching the consideration of what Stebbins (2008) termed 'serious leisure', participants are required to get involved, committing themselves in such a way with the activity they carry out that leads them to improve their performance and to establish a special relationship between the person and the activity (Romero et al., 2017). Participating in leisure activities is important for active ageing, contributing to increasing satisfaction with life and generally improving our quality of life; this impact will be reinforced if these experiences become significant and valuable for the person (Cuenca-Amigo and San Salvador, 2016).

On the other hand, if we analyse the self-attributions of each group and their attributions to others regarding the type of leisure activities and the time that older adults devote to them, we observe the possible influence of certain attribution biases and ageist stereotypes. Thus, both young people and the middle-aged group perceive older adults as a group that invests less time than they do in cultural and social leisure activities and much more in forms of passive leisure, which may be explained by ego-favourable attributions self-enhancement biases - in such a way that the group attributes more positive or less negative characteristics to itself than to other groups - that is, group favouritism (Brown et al., 1988). Said perception is shared by the group of older adults, who make attributions regarding their age group in a remarkably similar way to the other age groups, although with certain nuances - since older adults indicate that other older adults devote more time than themselves to all studied forms of leisure (social, cultural, passive and physical leisure), which seems to indicate a form of ageist self-stereotyping (Ayalon and TeschRömer, 2017). Stereotypes regarding ageing are progressively internalised and applied to oneself (Nascimento-Schulze, 2017). In other words, they become a self-fulfilling prophecy: the very fact that you are in a group subject to certain forms of stereotyping seems to contribute to reinforce the presence of these behaviours. Thus, for example, among the most common stereotypes applied to older adults there is the idea that older people have no sexual activity or that this is much lower, erroneously considering this stage of life as practically asexual (Cerquera et al., 2012; Lucas-Matheu, 2013); that they are not physically active (Emile et al., 2014); that they tend to get progressively isolated from others (Nunes et al., 2018); that they lack social networks (Cornwell et al., 2008); or that they share uniform traits (North and Fiske, 2013). An example of older adults' diversity is 
the so-called generation of 'woofs', which currently represents the paradigm of active and satisfactory ageing (Moreno Toledo et al., 2014), challenging the widespread image of old age as decay and fragility. Nevertheless, there seems to be a certain consistency among the different age groups studied in self-attributing fewer weekly hours to passive leisure activities, which are often assessed as less valuable for the individual, a trend that may also be affected by self-enhancing biases designed to preserve their self-esteem (Alicke and Sedikides, 2009).

Finally, to have a deeper degree as for the relationship between the different types of leisure, reliable predictors were sought. Regression analyses show that having a high level of education and being male accounts for Cultural Leisure; low level of knowledge about ageing and low satisfaction with ageing for Passive Leisure; the left-wing political ideology for Social Leisure; and the age for Physical Leisure, indicating that the older the age the fewer hours are devoted to activities related to physical leisure.

Our results are partially consistent with those studies that indicate that older people who participate in active leisure have higher levels of happiness and well-being (Yamashita et al., 2019). In a similar line, various studies found an association between satisfaction with subjective life/well-being and time spent on social and cultural leisure (Becchetti et al., 2012; Age UK, 2017). Conversely, high involvement in passive leisure activities, such as spending many hours watching television, negatively correlates with subjective well-being (Frey et al., 2007).

In light of the data from this study, we consider it necessary to make a series of reflections, which should be considered in the orientation of future social policies with the intention of contributing, from leisure, to achieving an active ageing of the population.

Firstly, in contrast to other studies, we have not found gender differences in leisure patterns: however, scientific literature has shown that gender uniquely limits the leisure of men and women (Yerkes et al., 2020), with leisure determined by gender social relations (Henderson and Gibson, 2013). However, we have found that older people have significantly lower levels of instruction than other age groups, and that this variable seems to influence leisure styles. Therefore, both issues - gender and level of instruction should be considered in policies and programs aimed at promoting leisure for older people, trying to reduce existing gender inequalities in economic, sociocultural or division of labour issues, as contemplated in previous studies (Zanjari et al., 2019; Fritzell et al., 2020). For example, it is argued that women have less leisure and lower quality because their total workload is higher, and they have more responsibility for caring for others (Henderson and Gibson, 2013).

Secondly, the leisure styles of older people seem to be influenced by cultural stereotypes, so it is necessary to promote actions to improve knowledge about ageing and eradicate the ageist stereotypes and self-stereotypes (Ayalon and Tesch-Römer, 2017).

Thirdly, social participation policies should pay attention to the sociocultural context and types of models applied. Molina et al. (2018) find differences in the rates of social participation between the northern European countries and those of the Mediterranean (Spain and Italy), suggesting as an explanation the different models of social policies implemented.

We understand that current social policies in the sociopolitical framework of Active Ageing could be oriented based on the data presented, developing policies that contribute through leisure to increase their levels of life satisfaction and quality of life. For this, it is necessary to implement initiatives that make possible a greater promotion of physical, 
social, and cultural leisure activities, paying special attention to the reduction of inequalities and the functional diversity of individuals.

This materialises in measures, among others, that are directed to 'teach to age' in line with the paradigm of active ageing, in improving knowledge about ageing and helping to eradicate stereotypes of older age, compensate for inequalities suffered by the rural environment in relation to the offer of leisure activities, services and equipment for this purpose, elimination of barriers that make it impossible or hinder the social participation of dependent old people, or promoting educational, strategies that promote a more equitable distribution between men and women of household tasks and involvement in family care.

This study has allowed us to describe the leisure patterns in older adults and to establish a comparison with other age groups, as well as to analyse their attributions in this respect - this is one of the main strengths of the study, as there are not too many investigations that opt for this comparative approach. We believe that the data obtained can be useful in designing policies and implementing programs aimed at promoting leisure styles that contribute to promoting active ageing. However, the research suffers from some limitations, among which we can mention the design used, the adjustment in the stratification of the sample by age and the research methodology.

However, research suffers from some limitations, including the design and research methodology used. Regarding the type of design, this research has chosen a cross-cutting study. To analyse the true effect of age on leisure patterns, a longitudinal design should be selected, which would allow us to study leisure practices throughout the life cycle of individuals, allowing us to capture the particular reality of each age group. Regarding the study methodology, this research opted for a quantitative model: however, to complete its analysis, a qualitative approach would possibly have been useful. Additionally, as for the sample, while its size is appropriate for the reference population, the percentage weight of the youth group is overrepresented; this mismatch is due to the intention to achieve more balanced groups in terms of size and to make the results of statistical analyses more reliable.

\section{References}

Abellán, A., Ayala, A. and Pujol, R. (2017) Un perfil de las personas mayores en España, 2017. Indicadores estadísticos básicos, Madrid: Consejo Superior de Investigaciones Científicas (CSIC), Centro de Ciencias Humanas y Sociales (CCHS), http:/envejecimiento.csic.es/documentos/documentos/ enred-indicadoresbasicos17.pdf [accessed 05.02.2020].

Acosta, C., Echeverría, S., Vales García, J., Ramos Estrada, D. and Bojórquez-Díaz, C. (2014) 'Variables psicosociales asociadas a la frecuencia de actividades de ocio en adultos mayores mexicanos', Psicología y Salud, 24, 109-19.

Age UK (2017) Methodology of Age UK's index of Wellbeing in Later Life, London: Tavistock House.

Alicke, M. and Sedikides, C. (2009) 'Self-enhancement and self-protection: what they are and what they do', European Review of Social Psychology, 20, 1-48. https://doi.org/10.1080/10463280802613866.

Alonso-Sánchez, M. F. (2017) 'Caracterización de las actividades de ocio como factor de Reserva Cognitiva: una revisión sistemática' Medicina Naturista, 11,2, 62-8.

Ayalon, L. and Tesch-Römer, C. (2017) 'Taking a closer look at ageism: self- and other-directed ageist attitudes and discrimination', European Journal of Ageing, 14, 1, 1-4.

Baltes, P. B., Reese, H. W. and Nesselroade, J. R. (1981) Métodos de investigación en psicología evolutiva. Enfoque del ciclo vital, Madrid: Morata. 
Bardo, A. R. (2017) 'A life course model for a domains-of-life approach to happiness: evidence from the United States', Advances in Life Course Research, 33, 11-22.

Becchetti, L., Giachin, E. and Pelloni, A. (2012) 'The relationship between social leisure and life satisfaction: causality and policy implications', Social Indicators Research, 108, 453-90.

Brown, J. D., Collins, R. L. and Schmidt, G. W. (1988) 'Self-esteem and direct versus indirect forms of selfenhancement', Journal of Personality and Social Psychology, 55, 3, 445-53.

Cerquera, A. M., Galvis, M. J. and Cala, M. L. (2012) 'Amor, sexualidad e inicio de nuevas relaciones en la vejez: percepción de tres grupos etario', Psychologia: Avances de la Disciplina, 6, 2, 73-81.

Cha, Y. (2018) 'Correlation between leisure activity time and life satisfaction: based on KOSTAT time use survey data', Occupational Therapy International, doi: 10.1155/2018/5154819.

Chang, P. Y., Wray, L. and Lin, Y. (2014) 'Social relationships, leisure activity, and health in older adults', Health Psychology, 33,6, 516-23.

CIRES (1996) Encuesta sobre uso del tiempo en España, Madrid: Centro de Investigaciones sobre la Realidad Social.

Cornwell, B., Laumann, E. O. and Schumm, L. P. (2008) 'The social connectedness of older adults: a national profile', American Sociological Review, 73, 2, 185-203.

Cuenca, M. (2009) 'Más allá del trabajo: el ocio de los jubilados', Revista Mal-Estar e Subjetividade, IX, 1, $13-42$.

Cuenca, J., Monteagudo, M. J. and Bayón, F. (2013) La contribución del ocio al envejecimiento satisfactorio de las personas mayores en Bizkaia, Vizcaya: Instituto de Estudios de Ocio.

Cuenca-Amigo, M. and San Salvador, R. (2016) 'La importancia del ocio como base para un envejecimiento activo y satisfactorio', Revista de Psicología del Deporte, 25(Suppl 2), 79-84.

Díaz, R. (coord.) (2012) Informe 2006. Las personas mayores en España, Madrid: Instituto de Mayores y Servicios Sociales.

Dionigi, R. A. (2015) 'Stereotypes of aging: their effects on the health of older adults', Journal of Geriatrics, 2015, 1, 1-9, doi: 10.1155/2015/954027.

Emile, M., Chalabaev, A., Stephan, Y., Corrion, K. and d'Arripe-Longueville, F. (2014) 'Aging stereotypes and active lifestyle: personal correlates of stereotype internalization and relationships with level of physical activity among older adults', Psychology of Sport and Exercise, 15, 198-204.

Eriksson Sörman, D., Sundström, A., Rönnlund, M., Adolfsson, R. and Nilsson, L. G. (2014) 'Leisure activity in old age and risk of dementia: a 15-year prospective study', Journals of Gerontology, Series B: Psychological Sciences and Social Sciences, 69, 4, 493-501, doi: 10.1093/geronb/gbt056.

Eurostat (2018) Estructura demográfica y envejecimiento de la población, https://ec.europa.eu/eurostat/ statistics-explained/index.php?title=Population_structureand_ageing/es\#El_porcentaje_de_personas_ mayores_sigue_aumentando [accessed 06.02.2020].

Felez-Nobrega, M., Raine, L.B., Haro, J. M., Wijndaele, K. and Kayanagi, A. (2020) 'Temporal trends in leisure-time sedentary behavior among adolescents aged 12-15 years from 26 countries in Asia, Africa, and the Americas', International Journal of Behavioral Nutrition and Physical Activity, 17, doi: 10.1186/s12966-020-01010-w.

Fernández-Mayoralas, G., Rojo-Pérez, F., Martínez-Martín, P., Prieto-Flores, M. E., Rodríguez-Blázquez, C., Martín-García, S., Rojo-Abuín, J. M. and Forjaz, M. J. (2015) 'Active ageing and quality of life: factors associated with participation in leisure activities among institutionalized older adults, with and without dementia', Aging and Mental Health, 19, 11, 1031-41.

Foster, L. and Walker, A. (2015) 'Active and successful ageing: a European policy perspective', Gerontologist, 55, 83-90.

Frey, B. S., Benesch, C. and Stutzer, A. (2007) 'Does watching TV make us happy?', Journal of Economic Psychology, 28, 3, 283-313.

Fritzell, J., Lennartsson, C. and Zaidi, A. (2020) 'Trends and inequality in the new active ageing and wellbeing index of the oldest old: a case study of Sweden', Journal of Population Ageing, doi: 10.1007/ s12062-020-09264-9. 
Genoe, M. R., Liechty, T. and Marston, H. R. (2019) 'Leisure innovation and the transition to retirement', Leisure Sciences, doi: 10.1080/01490400.2019.1597791.

Henderson, K. A. and Gibson, H. J. (2013) 'An integrative review of women, gender, and leisure: increasing complexities', Journal of Leisure Research, 45, 2, 115-35.

Kalache, A., Plouffe, L. and Voelcker, I. (2015) Envejecimiento activo. Un marco político ante la revolución de la longevidad, Río de Janeiro, Brasil: Centro Internacional de Longevidade Brasil.

Kim, J., Lee, S., Chun, S., Han, A. and Heo, J. (2017) 'The effects of leisure-time physical activity for optimism, life satisfaction, psychological well-being, and positive affect among older adults with Ioneliness', Annals of Leisure Research, 20, 4, doi: 10.1080/11745398.2016.1238308.

Kleiber, D. A. and Linde, B. D. (2014) 'The case for leisure education in preparation for the retirement transition', Journal of Parks and Recreation Administration, 32, 1, 110-27.

Lardiés-Bosque, R., Rojo Pérez, F., Rodríguez Rodríguez, V., Fernández-Mayoralas, G., Prieto-Flores, M. E. Ahmed Mohamed, K. and Rojo Abuín, M. (2013) 'Leisure activities and quality of life among old people in the region of Madrid', Boletín de la Asociación de Geógrafos Españoles, 63, 323-48.

Lawton, M. P. (1975) 'The Philadelphia Center Morale Scale: a revision', Journal of Gerontology, 30, 85-9.

Lee, H. J. and Yeong, Y. A. (2012) 'A correlation between leisure activities and life satisfactions of the old adults', Journal of Occupational Therapy for the Aged and Dementia, 6, 2, 47-53.

Levy, B. R., Slade, M. D., Kunkel, S. R. and Kasl, S. V. (2002) 'Longevity increased by positive selfperceptions of aging', Journal of Personality and Social Psychology, 83, 2, 261-70.

Liang, J. and Bollen, K. A. (1983) 'The structure of the Philadelphia Geriatric Center Morale Scale: a reinterpretation', Journal of Gerontology, 38, 181-89.

Lucas-Matheu, M. (2013) Sexualidad madura, Madrid, España: Síntesis.

Madrigal, A. (2000) 'La Soledad en las personas mayores', Boletín sobre Envejecimiento, 3, https://www. imserso.es/InterPresent2/groups/imserso/documents/binario/boletinopm3.pdf [accessed 05.02.2020].

Marhánkova, J.H. (2011) 'Leisure in old age: disciplinary practices surrounding the discourse of active ageing', Journal of Ageing and Later Life, 6, 5-32.

Marsillas, S., De Donder, L., Kardol, T., van Regenmortel, S., Dury, S., Brosens, D., Smetcoren, A. S., Braña, T. and Varela, J. (2017) 'Does active ageing contribute to life satisfaction for older people? Testing a new model of active ageing', European Journal of Ageing, 14, 3, 295-310.

Molina, M. A., Cañadas, J. L. and Serrano, R. (2018) 'Social participation of the elders in Europe: the influence of individual and contextual variables', Ageing International, 43, 190-206.

Monteagudo, M.J. and Cuenca, M. (2012) 'Los itinerarios de ocio desde la investigación: tendencias, retos y aportaciones', Pedagogía Social Revista Interuniversitaria, 20, 103-35.

Moreno Toledo, A., Díaz Henche, C., Toipa, D., Medina Armenteros, R., Brás Martins, F. and Del Avellanal Calzadill, A. (2014) 'El anciano woof o perfil simbólico del envejecimiento activo y saludable', Neurama Revista Electrónica de Psicogerontología, 1, 2, 4-14.

Nascimento-Schulze, C. M. (2017) 'A categoria sabedoria nos estudos sobre representações sociais do envelhecimento: uma revisão do conceito e de estudos relacionados', in A. Oliveira Silva and B. Vizeu Camargo, Representações sociais do envelhecimento e da saúde, Natal, Brasil: EDUFRN, 21-57.

North, M. S. and Fiske, S. T. (2013) 'Subtyping ageism: policy issues in succession and consumption', Social Issues and Policy Review, 7,1, 36-57.

Nunes, C., Menéndez, S., Martins, C. and Martins, H. (2018) 'Psychometric properties of the Negative Stereotypes Towards Aging Questionnaire (CENVE) among a sample of Portuguese adults', Psicologia: Reflexão e Crítica, 31, 3, 1-6.

Palmore, E.B. (1998) Facts on Aging Quiz: A Handbook of Uses and Results, 2nd edn, New York: Springer. Perales, J., Martin, S., Ayuso-Mateos, J. L., Chatterji, S., Garin, N., Koskinen, S., Leonardi, M., Miret, M., Moneta, V., Olaya, B., Tobiasz, B. and Haro, J. M. (2014) 'Factors associated with active aging in Finland, Poland, and Spain', International Psychogeriatrics, 26,8, 1363-75.

Pett, M. A., Lackey, N. R. and Sullivan, J. J. (2003) Making Sense of Factor Analysis: The Use of Factor Analysis for Instrument Development in Health Care Research, Thousand Oaks, California: SAGE Publications, INC. 
Pinazo, S., Lorente, X., Limón, R., Fernández, S. and Bermejo, L. (2010) 'Envejecimiento y aprendizaje a lo largo de la vida', in L. Bermejo, Envejecimiento Activo y Actividades Socioeducativas con Personas Mayores, Madrid, España: Editorial Médica Panamericana S.A., 3-10.

Punyakaew, A., Lersilp, S. and Putthinoi, S. (2019) 'Active ageing level and time use of elderly persons in a Thai suburban community', Occupational Therapy International, doi: 10.1155/2019/7092695.

Rodríguez, V., Fernández, G. and Rojo, F. (2012) 'Actividades de ocio y participación como base de una vejez activa', in D. Ramiro Fariñas (ed.), Una vejez activa en España. Informe del Grupo de Población del CSIC, Madrid: EDIMSA Editores Médicos, S.A., 53-80.

Romero, S., Iraurgi, I. and Madariaga, A. (2017) 'Valoración psicométrica de la versión española del SLIM (Serious Leisure Inventory and Measure) en contextos deportivos', Revista de Psicología del Deporte, 26, 2, 63-70.

Ryu, J. and Heo, J. (2018) 'Relationships between leisure activity types and well-being in older adults', Leisure Studies, 37, 3, 331-42.

Sancho, M. (2006) Informe 2006. Las personas mayores en España, Madrid: Instituto de Mayores y Servicios Sociales.

Stebbins, R.A. (2008) Serious Leisure: A Perspective for Our Time, New Jersey: Transaction.

United Nations (2017) World Population Prospects: The 2017 Revision, https://esa.un.org/unpd/wpp/ Publications/Files/WPP2017_KeyFindings.pdf [accessed 05.02.2020].

Walker, A. and Zaidi, A. (2016) 'New evidence on active ageing in Europa', Intereconomics, 51, 3, 139-44.

WHO (2002) Active Ageing: A Policy Framework, Geneva: World Health Organization, https://apps.who.int/ iris/bitstream/handle/10665/67215/WHO_NMH_NPH_02.8.pdf?sequence=1 \&isAllowed=y [accessed 05.02.2020].

WHO (2010) Global Recommendations on Physical Activity for Health, Geneva, Switzerland: World Health Organization.

Williams, B., Anderson, M. C. and Day, R. (2007) 'Undergraduate nursing students' knowledge of and attitudes toward aging: comparison of context-based learning and a traditional program', Journal of Nursing Education, 46, 115-20.

Yamashita, T., Bardo, A. and Liu, D. (2019) 'Experienced subjective well-being during physically active and passive leisure time activities among adults aged sixty-five years and older', Gerontologist, 59, 4, 718-26.

Yerkes, M. A. Roeters, A. and Baxter, J. (2020) 'Gender differences in the quality of leisure: a cross-national comparison, Community', Work and Family, 23, 4, 367-84.

Zanjari, N., Sadeghi, R. and Delbari, A. (2019) 'Analysis of gender differences in time use among Iranian older adults (Persian)', Salmand: Iranian Journal of Ageing, 13, Special Issue, 588-603. 